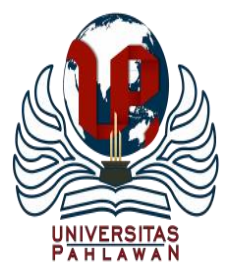

Edukatif : Jurnal Ilmu Pendidikan Volume 3 Nomor 1 Tahun 2021 Halm 235 - 245 EDUKATIF: JURNAL ILMU PENDIDIKAN

Research \& Learning in Education

https:/ledukatif.org/index.php/edukatif/index

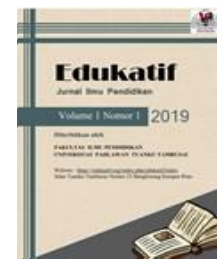

\title{
Analisis Model Pembelajaran Contextual Teaching and Learning dalam Meningkatkan Hasil Belajar PPKn di Sekolah Dasar
}

\author{
Irwan $^{1 凶}$, Hasnawi ${ }^{2}$ \\ Pendidikan Guru Sekolah Dasar, FKIP, Universitas Muhammadiyah Buton, Indonesia ${ }^{1,2}$ \\ E-mail : irwanlatif19@ gmail.com ${ }^{1}$, hasnawih553@ gmail.com ${ }^{2}$
}

\begin{abstract}
Abstrak
Permasalahan utama dalam penelitian yakni hasil belajar siswa masih rendah pada pelajaran PPKn. Penelitian ini bertujuan untuk menganalisis Model Pembelajaran Contextual Teaching and Learning dalam Meningkatkan Hasil Belajar PPKn Kelas III SDN 2 Laompo tahun pelajaran 2020/2021. Metode yang digunakan dalam penelitian yakni Penelitian Tindakan Kelas (PTK). Berdasarkan hasil analisis data penelitian menunjukkan bahwa nilai rata-rata pra siklus sebanyak 55,71\% dalam persentase ketuntasan klasikal yaitu 25\% sebelum menerapkan model Contextual Teaching And Learning. Nilai rata-rata siklus I sebanyak 66,42\% dalam bentuk persentase ketuntasan klasikal yaitu 50\% siswa yang tuntas atau di atas KKM berjumlah 14 siswa dan siswa belum tuntas atau di bawah KKM yaitu 14 siswa, karena belum mencapai nilai $\geq 70$ lanjutkan tindak siklus II. Nilai rata-rata siklus II sebanyak $77,86 \%$ dalam bentuk persentase ketuntasan klasikalnya yaitu $85.71 \%$, 24 siswa yang tuntas dan tidak tuntas 4 siswa atau $14.24 \%$. Hal ini menunjukkan bahwa penggunaan model Contextual Teaching and Learning dapat meningkatkan hasil belajar siswa, siswa yang memperoleh nilai $\geq 70$ sebesar $85.71 \%$. Implikasi penilitian menjadi bahan masukan bagi guru dan calon guru dalam pemilihan model pembelajaran untuk meningkatkan hasil maupun prestasi belajar siswa baik pada kelas rendah maupun kelas tinggi pada semua mata pelajaran.
\end{abstract}

Kata Kunci: Contextual Teaching and Learning, Hasil Belajar.

\begin{abstract}
The main problem in the research is that students' learning outcomes is still low, especially in PPKn lessons. This study aims to analyze the Contextual Teaching and Learning Model in Improving Class III PPKn Learning Outcomes of SDN 2 Laompo in the academic year of 2020/2021. The method used in this research is Classroom Action Research (CAR). The results of data analysis showed that the pre-cycle mean value was $55.71 \%$ in the percentage of classical completeness $(25 \%)$ before applying the Contextual Teaching and Learning model. The mean value of the first cycle was 66,42 \% in the form of a classical completeness percentage (50\%). 14 Students were categorized succeed in the learning and 14 students had not been able to achieve the minimum score, because they had not reached $\geq 70$ and had to continue to follow cycle II. The mean value of the second cycle was $77.86 \%$ in the form of the percentage of classical completeness of $85.71 \%$, 24 students succeed and the other 4 students did not (14.24\%). It shows that the use of the Contextual Teaching and Learning model can improve students' learning outcomes, students who scored $\geq 70$ were $85.71 \%$. The implication of this research becomes input for teachers and prospective teachers in the selection of learning models to improve students' learning outcomes and achievements in both low and high classes in all subjects.

Keywords: Contextual Teaching and Learning, Learning Outcomes.
\end{abstract}

Copyright (c) 2021 Irwan, Hasnawi

$\triangle$ Corresponding author

Email : irwanlatif19@gmail.com

DOI : https://doi.org/10.31004/edukatif.v3i1.343

ISSN 2656-8063 (Media Cetak)

ISSN 2656-8071 (Media Online)

Edukatif : Jurnal Ilmu Pendidikan Vol 3 No 1 Tahun 2021 p-ISSN 2656-8063 e-ISSN 2656-8071 
236 Analisis Model Pembelajaran Contextual Teaching and Learning dalam Meningkatkan Hasil Belajar PPKn di Sekolah Dasar - Irwan, Hasnawi

DOI: https://doi.org/10.31004/edukatif.v3i1.343

\section{PENDAHULUAN}

Pendidikan adalah komponen penting dari perkembangan suatu negara akan menghasilkan sumber daya manusia yang berkualitas jika pendidikan berkualitas tinggi. (Undang-undang Republik Indonesia Nomor 20 Tahun 2003, 2003) dijelaskan bahwa tujuan pendidikan nasional adalah mengembangkan kemampuan dan membentuk karakter serta masyarakat bangsa yang berintegritas dalam arti mencerdaskan kehidupan bangsa, dengan tujuan untuk mengembangkan kapasitas peserta didik untuk menjadi manusia yang beriman dan bertakwa kepada Tuhan Yang Maha Esa, berakhlak mulia, orang yang bugar, berwawasan, kompeten, imajinatif, dan mandiri, serta warga negara yang demokratis dan bertanggung jawab.

(Wahyudin \& Susilana, 2011) mengartikan pendidikan sebagai "upaya memanusiakan manusia atau upaya manusia untuk mengenal manusia, memahami, dan lebih dewasa, serta mampu menjadikan manusia lebih kritis dalam berfikir". Untuk melaksanakan kegiatan tersebut, lembaga pendidikan harus berupaya mengembangkan pendidikan dan mengajak masyarakat dari berbagai lapisan masyarakat untuk berpartisipasi aktif dalam meningkatkan taraf pendidik di Indonesia. Kualitas pendidikan akan lebih bermutu jika menggunakan berbagai metode yang memadai. Metode pendidikan merupakan proses memahami kehidupan sosial manusia agar peserta didik memiliki peran yang potensial dalam kehidupannya. Oleh karena itu, setiap pengelola lembaga pendidikan yang terlibat dalam penyelenggaraan pendidikan harus memahami arti dan maksud pendidikan, karena pada dasarnya mencerdaskan anak bangsa.

Pemahaman dan hasil belajar siswa sangat tergantung dari seorang guru karena guru memiliki pengaruh yang signifikan terhadap proses belajar mengajar di kelas. Sehingga pada pembelajaran PPKn, pemilihan metode pembelajaran yang tepat akan membantu siswa menjadi lebih terlibat dan mengembangkan karakter serta keterampilan sosial. Fungsi guru adalah memfasilitasi pembentukan dan perkembangan informasi, bukan untuk menggerakkannya siswa. Penting untuk dipahami bahwa tujuan pembelajaran, konsistensi dengan isi pembelajaran, kompetensi dasar yang diharapkan, tingkat kemajuan siswa, kapasitas guru dalam belajar, optimalisasi perangkat pembelajaran yang mempengaruhi proses dan hasil pembelajaran.

Salah satu penerapan model yang beragam yaitu penerapan model pembelajaran Contextual Teaching and Learning (CTL) karena model CTL ini memiliki ciri-ciri, seperti keadaan saat ini yang secara langsung mempengaruhi kehidupan siswa, pembelajaran yang tidak terbatas di dalam kelas, dan pembelajaran yang terjadi dengan cara yang nyaman agar siswa belajar dengan penuh semangat dan tidak bosan.(Dwi Putri Yesya \& Desyandri, 2018). Penerapan model pembelajaran Contextual Teaching and Learning (CTL) merupakan salah satu hal yang dapat mengantisipasi permsalahan pembelajaran di sekolah tersebut. CTL merupakan filosofi pembelajaran yang memungkinkan siswa untuk menghubungkan antara pengetahuannya dengan implementasinya dalam kehidupan sehari-hari dengan membantu guru dalam menghubungkan informasi dengan keadaan siswa di dunia nyata (Rusman, 2013). Pembelajaran CTL lebih tertarik untuk membantu siswa dalam mencari kesempatan untuk menjalani apa yang mereka pelajari daripada sekedar mentransfer informasi dari guru kepada siswa dengan menghafal berbagai prinsip yang tampaknya berasal dari kehidupan nyata. Oleh karena itu, Model pembelajaran kontekstual telah dikembangkan dan diterapkan dengan cermat. Hal ini diharapkan dapat memotivasi siswa untuk mengembangkan kemampuannya dalam mempersiapkan pelajaran. Peningkatan motivasi belajar siswa juga diharapkan berdampak positif, dengan hasil belajar PPKn yang semakin meningkat. (Rademan et al., 2020). Merujuk pada penelitian yang dilakukan bahwa pembelajaran kontekstual merupakan adalah suatu metode pengajaran yang menghubungkan materi yang dipelajari siswa dengan kehidupan sehari-hari secara fakta (Mandasari, 2019).

Penelitian ini berjudul "Analisis Model Pembelajaran Contextual Teaching and Learning dalam Meningkatkan Hasil Belajar PPKn Kelas III SDN 2 Laomp. Penelitian ini sangat penting untuk dilakukan karena dapat meningkatkan hasil belajar dan siswa lebih peka apa yang dipelajari berdampak kehidupan fakta, 
sehingga penggunaan meode CTL sebagai salah satu model yang dapat memberi kontribusi dalam pembelajaran. Judul penelitian ini sudah pernah diteliti oleh peneliti sebelumnya namun letak kebaruan pada penelitian yaitu pada penelitian sebelumnya model Contextual Teaching and Learning lebih diterapkan pada kelas tinggi, sedangkan pada penelitian ini, model Contextual Teaching and Learning diterapakan pada kelas rendah sekolah dasar, sehingga ada perbedaan yang ditemukan dalam penelitian baik pada karakter maupun hasil belajar siswa.

Mengacu pada harapan yang dikemukakan oleh para ahli bahwa model CTL merupakan suatu model yang dapat mengaktifkan siswa dan siswa belajar sesuai fakta dalam kehidupan sehari-hari. Jika memperhatikan fakta harapan yang dikemukakan para ahli belum tercapai dengan maksimal. Banyak faktor yang menyebabkan baik secara internal maupun secara eksternal. Berdasarkan kenyataan di lapangan menunjukkan bahwa di SD Negeri 2 Laompo hasil belajar siswa masih rendah pada mata pelajaran PPKn. Permasalahan tersebut terbukti dari jumlah 28 siswa, terdapat 7 siswa atau 25\% yang mendapat nilai lebih atau sama dengan KKM 70, sementara yang mendapatkan nilai di bawah KKM adalah 21 siswa atau $75 \%$. Rendahnya hasil belajar siswa kelas III SD Negeri 2 Laompo diketahui permasalahanya yaitu dalam proses pembelajaran masih banyak siswa yang mengobrol sesama teman dan kurang memperhatikan penjelasan guru, siswa kurang bertanggung jawab terhadap tugas yang diberikan guru dan metode pembelajaran yang digunakan kurnag bervariasi dalam hal ini lebih banyak ceramah, sehingga membuat siswa terlihat kurang semangat. Penelitian ini difokuskan pada rendahnya hasil belajar siswa di SD Negeri 2 Laompo, hasil belajar PPKn siswa perlu diperkuat karena memperhatikan sekolah merupakan tempat di mana pendidikan dan kesadaran serta keterampilan siswa harus dibangun dengan baik, karena hal ini sangat penting dalam pemecahan masalah yang dihadapi di sekolah.

\section{METODE PENELITIAN}

Metode Penelitian yang digunakan dalam penelitian ini adalah penelitian tindakan kelas yang dilakukan dalam rangka meningkatkan atau memperbaiki mutu praktek pembelajaran yang dilakukan secara sistematis mulai dari perencanaan sampai kepada refleksi. Subjek dalam penelitian ini adalah siswa-siswi kelas III SD Negeri Negeri 2 Laompo Tahun Pelajaran 2020/2021 dengan jumlah siswa sebanyak 28 orang siswa yang terdiri 14 siswa perempuan dan 14 siswa laki-laki. Penelitian ini dilakukan selama \pm 1 bulan. Secara garis besar terdapat empat tahapan atau prosedur yang yang digunakan dalam penelitian yaitu (1) perencanaan, (2) pelaksanaan, (3) pengamatan dan (4) refleksi. (Arikunto, 2014). Adapun tahapan dalam penelitian ini adalah sebagai berikut :

1). Tahap Perencanaan, pada tahap ini yang dilakukan yaitu membuat secara rinci rancangan tindakan meliputi : a). Peneliti dan guru melakukan dan menentukan rancangan pembelajaran tentang Arti Gambar pada Lambang Negara Garuda Pancasila model Contextual Teaching and Learning. b) Merancang pengorganisasian kelas. c) Menetapkan dan menyusun deskipsi serta indikator sebagai kriteria untuk mengukur keberhasilan perencanaan, pelaksanaan, dan penilaian pembelajaran tentang Arti Gambar pada Lambang Negara Garuda Pancasila.

2). Tahap Pelaksanaan Tindakan, pada tahap ini peneliti dan guru melaksanakan rencana tindakan yang telah disusun dalam bentuk siklus tindakan. Adapun prosedur pelaksanaan tindakan, yaitu : (a) Guru melaksanakan kegiatan pembelajaran harus sesuai RPP yang telah disusun, dan bila memungkinkan pelaksanaan pembelajaran dapat dilakukan secara bergantian antara guru dan peneliti. (b) Peneliti mengamati proses pembelajaran tentang Arti Gambar pada Lambang Negara Garuda Pancasila yang dilakukan guru dan pengelolaan pembelajaran. (c) Peneliti dan guru berkolaborasi dalam penilain hasil pembelajaran tentang Arti 
Gambar pada Lambang Negara Garuda Pancasila. Hasil tersebut dijadikan bahan pertimbangan dalam bentuk keberhasilan yang telah dicapai dari yang belum tercapai.

3). Tahap Pengamatan, observasi (pengamatan) dilakukan bersamaan dengan tahap pelaksanaan tindakan. Observasi dilakukan oleh guru PPKn Kelas III SD Negeri 2 Laompo. Pengumpulan data di lakukan dengan mengisi lembar observasi/penilaian yang telah disusun.

4). Tahap Refleksi, temuan yang diperoleh melalui tahap pengamatan berdasarkan kondisi objektif. Bertolak dari hasil pembelajaran Arti Gambar pada Lambang Negara Garuda Pancasila yang dicapai dalam pelaksanaan kegiatan pembelajaran yang dilakukan guru dan jenis kesalahan. Peneliti merumuskan refleksi lanjutan dalam melakukan tindakan pada siklus berikutnya. Langkah kegiatan tesebut bertujuan untuk membenahi kelemahan yang terdapat dalam kegiatan pembelajaran menghargai dan menaati keputusan bersama dengan menggunakan model Contextual Teaching and Learning.

Teknik pengumpulan data dilakukan dengan cara tes hasil belajar (Tes yang digunakan adalah berbentuk uraian. Pemberian tes dilakukan sebanyak tiga kali, yaitu tes awal (sebelum pemberian tindakan), tes pemberian tindakan, dan tes hasil belajar (setelah pemberian tindakan). Tes berbentuk uraian diberikan dengan tujuan untuk mengetahui sejauh mana siswa mendalami materi pokok yang diajarkan. Tes ini di berikan setelah pembelajaran dilaksanakan dan dari hasil tes akan di lihat apakah ada peningkatan hasil belajar siswa), observasi (Observasi dilakukan oleh guru PPKn di sekolah tempat penelitian berlangsun untuk mengamati peneliti dan siswa selama kegiatan belajar mengajar berlangsung), dan dokumentasi. Dalam pelaksanaan penelitian tidak dilakukan secara mandiri akan tetapi melibatkan guru kelas guna unuk memecahkan permasalahan di kelas. Peneliti mempersiapkan berbagai perangkat yang berkaitan dengan penelitian untuk meningkatakan hasil belajar siswa. Analisis data dilakukan dengan cara mengelompokkan data tentang aktivitas siswa selama proses pembelajaran berlangsung dan data hasil observasi dianalisis dengan menggunakan analisis deskriptif sehingga diperoleh nilai rata-rata, dan persentase aktivitas guru dan murid. (Pantiwati, 2014). Adapun rumus yang digunakan yaitu:

1. Rumus menghitung ketercapaian hasil belajar siswa menggunakan rumus sebagai berikut (Sudjana, 2009):

$$
\mathbf{M}=\frac{\sum \times}{\mathbf{N}}
$$

Keterangan $: \mathrm{M}($ Mean $)=$ nilai rata-rata kelas, $\sum \times=$ jumlah seluruh nilai, $\mathrm{N}=$ jumlah siswa

Perhitungan hasil belajar siswa ditafsirkan dalam kriteria

Hasil penghitungan rata-rata dikonsultasikan dengan kriteria ketuntasan belajar siswa yang dikelompokkan ke dalam dua kategori tuntas dan tidak tuntas.

2. Rumus menghitung ketercapaian hasil belajar siswa menggunakan rumus :

$$
\mathrm{KB}=\frac{\mathrm{NS}}{\mathrm{N}} \times 100 \%(\text { Susanto, 2013) }
$$

Keterangan: $\mathrm{KB}=$ Ketuntasan Belajar Klasikal, NS= Jumlah siswa yang mendapatkan nilai $\geq 70, \mathrm{~N}=$ Jumlah siswa yang hadir mengikuti tes (Aqib \& Amrullah, 2018).

\section{HASIL DAN PEMBAHASAN}

Penelitian Tindakan Kelas (PTK) ini meliputi II siklus yaitu siklus I dan siklus II. Setiap siklus terdiri dari tahap perencanaan, pelaksanaan tindakan, observasi dan refleksi. 
Sebelum melaksanakan Penelitian Tindakan Kelas (PTK), peneliti melakukan kegiatan pra siklus atau tes awal dilaksanakan pada hari selasa dan rabu tanggal 25-26 Agustus 2020. Pada pra siklus ini materi yang diajarkan adalah materi arti gambar pada lambang negara Garuda Pancasila pada tahun ajaran 2020/2021. Tahap ini bertujuan untuk mengetahui hasil belajar siswa dalam pembelajaran PPKn di kelas sebelum diterapkan model pembelajaran CTL (Contextual Teaching and Learning).

Hasil pra siklus digunakan sebagai penguat untuk mengetahui hasil belajar siswa sebelum dilaksanakan tindakan penelitian. Temuan awal hasil belajar siswa pada rencana pembelajaran dapat dilihat pada tabel berikut:

Table 1. Hasil Belajar Siswa pada Pra Siklus

\begin{tabular}{|c|c|c|}
\hline Hasil pra siklus & \multicolumn{2}{|c|}{ Nilai } \\
\hline Rata-rata & \multicolumn{2}{|c|}{$55,71 \%$} \\
\hline Tuntas & 7 & $25 \%$ \\
\hline Tidak Tuntas & 21 & $75 \%$ \\
\hline Jumlah & 28 & $100 \%$ \\
\hline
\end{tabular}

Dari data tabel 1 tersebut terlihat bahwa nilai rata-rata hasil belajar siswa adalah sebanyak $55,71 \%$ dari jumlah 28 siswa. Jumlah siswa yang mencapai nilai KKM sebanyak 7 siswa atau sebanyak $25 \%$, sedangkan jumlah siswa yang di bawah nilai KKM sebanyak 21 siswa atau 75\%. Berdasarkan hasil belajar yang diperoleh tentu belum memenuhi KKM yang telah ditentukan, maka peneliti bermaksud memperbaiki dan meningkatkan hasil belajar siswa kelas III dengan menggunakan model Contextual Teaching and Learning pada pembelajaran PPKn. Maksud dan tujuan mengalami peningkatan hasil belajar siswa yang baik. Atas dasar pra siklus ini menjadi hal yang sangat penting untuk menerapkan dan memperbaiki proses yang telah dilakukan di sekolah.

Pada tahap siklus I dilaksanakan pada hari selasa dan rabu tanggal 1-2 September 2020. Tahap ini terdiri dari 4 tahap, yaitu: tahap perencanaan tindakan, tahap pelaksaan tindakan, tahap observasi, dan tahap refleksi yang dijelaskan sebagai berikut:

Pada tahap perencanaan siklus I, peneliti mempersiapkan perencanaan yang matang agar pengajaran dapat tercapai dengan baik, dengan langkah-langkah: (1) melakukan koordinasi dengan guru kelas mengenai rencana penelitian yang dilakukan, (2) menyusun rencana pelaksanaan pembelajaran PPKn dengan menggunakan model CTL, (3) menyusun tes materi arti gambar pada lambang negara Garuda Pancasila dengan menggunakan model CTL, (4) Penyusunan instrumen penelitian berupa lembar observasi aktivitas siswa melalui model pembelajaran CTL (Contextual Teaching and Learning) dan tes hasil belajar siswa.

Pada tahap ini, kegiatan pembelajaran dengan menggunakan model CTL (Contextual Teaching and Learning). Tahap-tahap pelaksanaan pembelajaran yang dilaksanakan pada penelitian tindakan kelas pada siklus I adalah (1) Pendahuluan: Guru memberikan salam dan mengajak semua siswa berdoa menurut agama dan keyakinan masing-masing, guru mengecek kehadiran siswa, kegiatan pembelajaran diawali dengan mengamati gambar yang ada di buku siswa, siswa diminta untuk mengamati gambar yang ada di buku siswa, siswa diminta memberikan pendapat tentang kegiatan yang terjadi pada gambar tersebut, guru memberikan pendapatnya tentang kegiatan yang terjadi pada gambar tersebut, dan guru menyampaikan tujuan pembelajaran akan dicapai dalam proses pembelajaran. (2) Kegiatan Inti: Guru akan melakukan penyampaian materi pembelajaran dengan menggunakan model CTL (Contextual Teaching and Learning) dengan tahapan sebagai berikut: (1) Guru menjelaskan materi yang akan ajarkan yaitu: "Arti Gambar pada Lambang negara Garuda Pancasila dengan benar", (2) Guru membagi siswa menjadi 5 kelompok, (3) Guru membagikan LKS dan menjelaskan hal-hal yang harus dilakukan siswa, (4) Siswa mengerjakan LKS yang diberikan guru, (5) 
Siswa mencatat data hasil diskusi pada lembar kerja siswa, (6) Setiap kelompok berdiskusi untuk mengembangkan hasil yang sudah dapat, (7) Beberapa siswa mempersentasikan data hasil diskusi masingmasing kelompok mereka, dan (8) Siswa bersama guru menyimpulkan materi yang telah dipelajari. (3) Penutup: Guru menginformasikan materi yang akan dipelajari selanjutnya, guru memberikan tugas rumah kepada siswa, guru memberikan tindak lanjut berupa pemberian motivasi, dan guru mengajak semua siswa berdoa menurut agama dan keyakinannya masing-masing.

Pada tahap observasi ini, peneliti menggunakan hasil observasi digunakan untuk mengetahui kemajuan yang dicapai siswa dalam meningkatkan hasil belajar siswa dengan menggunakan model CTL (Contextual Teaching and Learning). Pengamatan dilakukan oleh peneliti selama proses pembelajaran berlangsung. Peneliti mencatat siswa yang aktif, siswa yang kurang memperhatikan, yang bercakap-cakap, dan sebagainya. Tahap ini sangat penting dan membutuhkan pengamatan yang teliti serta sabar demi memberikan masukan pada perbaikan siklus selanjutnya. Diakhir siklus I dilakukan pula tes untuk mengetahui hasil belajar siswa. Dapat dilihat pada tabel 3 sebagai berikut:

Tabel 2. Nilai Siswa pada Siklus I

\begin{tabular}{|c|c|c|}
\hline Hasil pra siklus & \multicolumn{2}{|c|}{ Nilai } \\
\hline Rata-rata & \multicolumn{2}{|c|}{$66,42 \%$} \\
\hline Tuntas & 14 & $50 \%$ \\
\hline Tidak Tuntas & 14 & $50 \%$ \\
\hline Jumlah & 28 & $100 \%$ \\
\hline
\end{tabular}

Berdasarkan tabel 2, maka dapat disimpulkan bahwa nilai hasil belajar siswa pada siklus I mengalami sedikit peningkatan jika dibandingkan pada pra siklus, dengan jumlah 28 siswa. Menurut (Suyono, 2016) ciriciri pembelajaran meliputi pergeseran tindakan (changebehavior). Hanya perubahan dalam tindakan, dari tidak memahami menjadi mengetahui, dari tidak terampil menjadi profesional, yang diamati sebagai hasil pembelajaran. Siswa yang mendapatkan nilai di atas KKM sebanyak 14 siswa atau 50\%, sedangkan siswa yang mendapatkan nilai di bawah KKM sebanyak 14 siswa 50\%. Nilai tertinggi adalah 80, sedangkan nilai terendahnya adalah 50 dengan jumlah rata-rata yang diperoleh dari siklus I yaitu 66,42\%.

Pada tahap refleksi ini dilakukan oleh peneliti berdasarkan hasil observasi dan evaluasi hasil pembelajaran PPKn dengan model pembelajaran CTL. Hasil observasi untuk melihat apakah kegiatan yang dilakukan telah meningkatkan hasil belajar siswa. Kenyataannya bahwa mengalami peningkatan hasil belajar dibandingkan pada nilai hasil belajar pra siklus, meskipun demikian ada beberapa permasalahan yang terjadi diantaranya siswa belum semua paham dengan model pembelajaran yang diterapkan, beberapa siswa bingung dengan kelompoknya dan beberapa siswa saat presenasi materi masih bingung dengan materi yang dibacakan, sehingga berpengaruh pula pada hasil belajar siswa.

Pada tahap siklus II dilaksanakan pada hari selasa dan rabu tanggal 8-9 September 2020 yang terdiri dari 4 tahap, yaitu: tahap perencanaan tindakan, tahap pelaksaan tindakan, tahap observasi, dan tahap refleksi. Dari keempat tahap tersebut akan dijelaskan sebagai berikut:

Pada pelaksanaan siklus II proses pembelajaran dimulai dengan, mengingatkan hal-hal yang menjadi kekurangan di siklus I agar pelaksanaa di siklus II ini tidak terjadi lagi. Proses pembelajaran dalam siklus II, peneliti lebih berusaha membuat sifat semangat dalam diri siswa, memotivasi siswa supaya lebih aktif pada proses pembelajaran maupun dalam proses kerja kelompok berlangsung, guru juga berusaha untuk mengelola waktu dengan baik agar menggunakan rencana pembelajaran siswa lebih aktif. Siswa diharapakan pelaksanaan siklus II suasana pembelajaran tidak kaku sehingga keaktivan siswa, kerjasama pada kelompok maupun hasil belajar individunya meningkat. 
Tahap perencanaan, peneliti mempersiapkan perbaikan-perbaikan yang dilakukan sebagai bentuk perencanaan pada siklus II ini meliputi: (1) memperbaiki rencana pelaksanaan kemampuan meningkatan hasil belajar siswa dengan menggunakan model pembelajaran CTL, (2) memperbaiki kesalahan pada siklus I berkaitan dengan kemampuan meningkatan hasil belajar siswa dengan menggunakan model pembelajaran CTL (3) penguatan unsur-unsur penting dalam peningkatan hasil belajar, dan (4) keterlibatan guru dalam proses pembelajaran materi arti gambar pada lambang negara Garuda Pancasila dengan meng gunakan model pembelajaran CTL pada siswa kelas III SD Negeri 2 Laompo Kabupaten Buton Selatan.

Pada tahap ini, kegiatan pembelajaran dengan menggunakan model CTL (Contextual Teaching and Learning). Tahap-tahap pelaksanaan pembelajaran yang dilaksanakan pada penelitian tindakan kelas pada siklus I adalah (1) Pendahuluan: Guru memberikan salam dan mengajak semua siswa berdoa menurut agama dan keyakinan masing-masing, guru mengecek kehadiran siswa, kegiatan pembelajaran diawali dengan mengamati gambar yang ada di buku siswa, siswa diminta untuk mengamati gambar yang ada di buku siswa, siswa diminta memberikan pendapat tentang kegiatan yang terjadi pada gambar tersebut, guru memberikan pendapatnya tentang kegiatan yang terjadi pada gambar tersebut, dan guru menyampaikan tujuan pembelajaran akan dicapai dalam proses pembelajaran. (2) Kegiatan Inti: Guru akan melakukan penyampaian materi pembelajaran dengan menggunakan model CTL (Contextual Teaching and Learning) dengan tahapan sebagai berikut: (1) Guru menjelaskan materi yang akan ajarkan yaitu: Arti gambar pada lambang negara Garuda Pancasila dengan benar, (2) Guru membagi siswa menjadi 5 kelompok, (3) Guru membagikan LKS dan menjelaskan hal-hal yang harus dilakukan siswa, (4) Siswa mengerjakan LKS yang diberikan guru, (5) Siswa mencatat data hasil diskusi pada lembar kerja siswa, (6) Setiap kelompok berdiskusi untuk mengembangkan hasil yang sudah didapat, (7) Beberapa siswa mempersentasikan data hasil diskusi masingmasing kelompok mereka, dan (8) Siswa bersama guru menyimpulkan materi yang telah dipelajari. (3) Penutup: Guru menginformasikan materi yang akan dipelajari selanjutnya, guru memberikan tugas rumah kepada siswa, guru memberikan tindak lanjut berupa pemberian motivasi, dan guru mengajak semua siswa berdoa menurut agama dan keyakinannya masing-masing.

Berdasarkan data yang diperoleh melalui lembar observasi aktivitas siswa dan guru dapat di simpulkan yaitu Dengan ditingkatkannya keterampilan mengelola kelas oleh guru sehingga suasana dalam kelas menjadi hangat dan terkendali dan dengan serius seluruh siswa memperhatikan penjelasan guru walaupun masih ada satu dua orang siswa yang bermain. Siswa semakin banyak yang mau bertanya hal-hal yang kurang dimengerti, seiring dengan sikap guru memberikan respon yang ramah dan menyenangkan sehingga timbul keberanian siswa untuk bertanya, sehingga sesekali siswa mengajak gurunya bercanda. Hasil tersebut dapat dilihat pada tabel sebagai berikut:

Tabel 3. Nilai Siswa pada Siklus II

\begin{tabular}{|c|c|c|}
\hline Hasil siklus II & \multicolumn{2}{|c|}{ Nilai } \\
\hline Rata-rata & \multicolumn{2}{|c|}{$77.86 \%$} \\
\hline Tuntas & 24 & $85,72 \%$ \\
\hline Tidak Tuntas & 4 & $14,28 \%$ \\
\hline Jumlah & 28 & $100 \%$ \\
\hline
\end{tabular}

Pada tabel 3 di atas, maka dapat dilihat bahwa hasil tes siklus II sudah masuk kategori baik dan hasil belajar siswa lebih meningkat dari siklus I. Ketika perilaku seseorang berubah, dia dikatakan sedang belajar. (Susanto, 2013) selanjutnya mengatakan bahwa belajar adalah proses, bukan produk atau target. Jadi, pembelajaran memerlukan lebih dari sekedar mengingat atau menghafal informasi; itu juga memerlukan mengalami pergeseran pada diri siswa. Hasil hasil belajar siklus I bahwa siswa yang mendapatkan nilai di atas KKM sebanyak 24 siswa dalam bentuk persennya yaitu $85,71 \%$, sedangkan siswa yang di bawah nilai KKM 
sebanyak 4 siswa dalam bentuk persennya yaitu 14,28\%. Nilai tertinggi adalah 100 dan nilai terendahnya adalah 60 dengan nilai rata-rata 77,86\%. Hasil di atas menunjukan bahwa indikator keberhasilan penelitian ini yaitu hasil tes untuk setiap siswa pada akhir pembelajaran mencapai nilai $\geq 70 \mathrm{KKM}$ yang ditetapkan oleh sekolah dan nilai persentase siswa secara klasikal telah tercapai yaitu $77,86 \%$.

Berdasarkan hasil refleksi, langkah-langkah yang disusun dalam rencana pelaksanaan pembelajaran telah dilakukan dengan maksimal. Pada siklus II, permasalah yang muncul pada siklus I dapat teratasi dengan baik walaupun cukup memakan waktu yang banyak. Hal ini dapat dilihat dari hasil tes siklus II mengalami peningkatan dibandingkan dengan siklus I. Hasil belajar pada dasarnya kompetensi yang dimiliki seseorang sesudah mengikuti pembelajaran. Hal ini seperti yang dikemukakan oleh (S, 2015) bahwa hasil belajar merupakan proses dan tahapan dalam mencapai sesuatu yang nyata diperlihatkan dalam model sikap, habitual dan reward yang diberikan atas hasil dari pembelajaran. Selanjutnya hasil belajar menurut (Susanto, 2013) merupakan proses transisi di mana aspek kognitif (pemahaman konsep), afektif (sikap), dan psikomotor (keterampilan proses) siswa mengalami perubahan sebagai akibat dari pengalaman belajar. Dari hasil yang diperoleh pada penelitian ini dari data tes hasil belajar siswa dan hasil observasi aktivitas siswa selama pelaksanaan pembelajaran mengalami peningkatan. Hasil dari kedua siklus digunakan untuk mengetahui peningkatan hasil belajar siswa tentang materi arti gambar pada lambang negara Garuda Pancasila melalui Model Pembelajaran CTL (Contextual Teaching and Learning). Salah satu pendekatan pembelajaran yang dapat meningkatkan kreativitas siswa dalah pendekatan kontekstual. Pendekatan kontekstual merupakan salah satu metode pembelajaran yang dapat membantu siswa menjadi lebih kreatif. (Asra, 2019).

Berdasarkan hasil data yang telah dicapai persiklus mengalami peningkatan perbaikan pembelajaran dimana pada pra siklus $25 \%$ dengan nilai rata-rata 55.71 , pada siklus I menjadi $50 \%$ dengan nilai rata-rata $66,42 \%$, siklus II meningkat sebesar $85,71 \%$ dengan rata-rata 77,86\%. Berdasarkan (Depdiknas, 2006) bahwa pembelajaran dikatakan tuntas apabila secara klasikal siswa yang mendapatkan nilai 70 ke atas mencapai 85\%, maka dari penerapan model tersebut pada pembelajaran PPKn maka telah mencapai hasil diharapkan. Hal ini dapat terlihat pada tabel yang menadi perbandingan dari hasil belajar yang diperoleh tiap siklus.

Tabel 4. Akumulasi Hasil Belajar Siswa Pra Siklus, Siklus I dan Siklus II

\begin{tabular}{|c|c|c|c|c|c|c|}
\hline \multirow{2}{*}{ Ketuntasan } & \multicolumn{2}{|c|}{ Pra Siklus } & \multicolumn{2}{c|}{ Siklus I } & \multicolumn{2}{c|}{ Siklus II } \\
\cline { 2 - 7 } & Frekuensi & $\mathbf{\%}$ & Frekuensi & \% & Frekuensi & \% \\
\hline Tuntas & 7 & $25 \%$ & 14 & $50 \%$ & 24 & $85 \%$ \\
\hline Tidak Tuntas & 21 & $75 \%$ & 14 & $50 \%$ & 4 & $14 \%$ \\
\hline Jumlah & 28 & $100 \%$ & 28 & $100 \%$ & 28 & $100 \%$ \\
\hline
\end{tabular}

Berdasarkan Tabel 4.1 dapat dilihat bahwa adanya peningkatan hasil belajar siswa setelah dilakukan tindakan. Dalam hal ini peneliti memecahkan permasalahan dari pra siklus nilai rata-rata $55,71 \%$, siklus I nilai rata-rata $66,42 \%$, dan siklus II meningkat menjadi 77,86\% maka dapat disimpulkan bahwa penggunaan model CTL (Contextual Teaching and Learning) dalam pembelajaran PPKn dapat meningkatkan hasil belajar siswa Kelas III SD Negeri 2 Laompo Kabupaten Buton Selatan. 
243 Analisis Model Pembelajaran Contextual Teaching and Learning dalam Meningkatkan Hasil Belajar PPKn di Sekolah Dasar - Irwan, Hasnawi

DOI: https://doi.org/10.31004/edukatif.v3i1.343

Dari hasil di atas dapat disajikan pada diagram berikut:

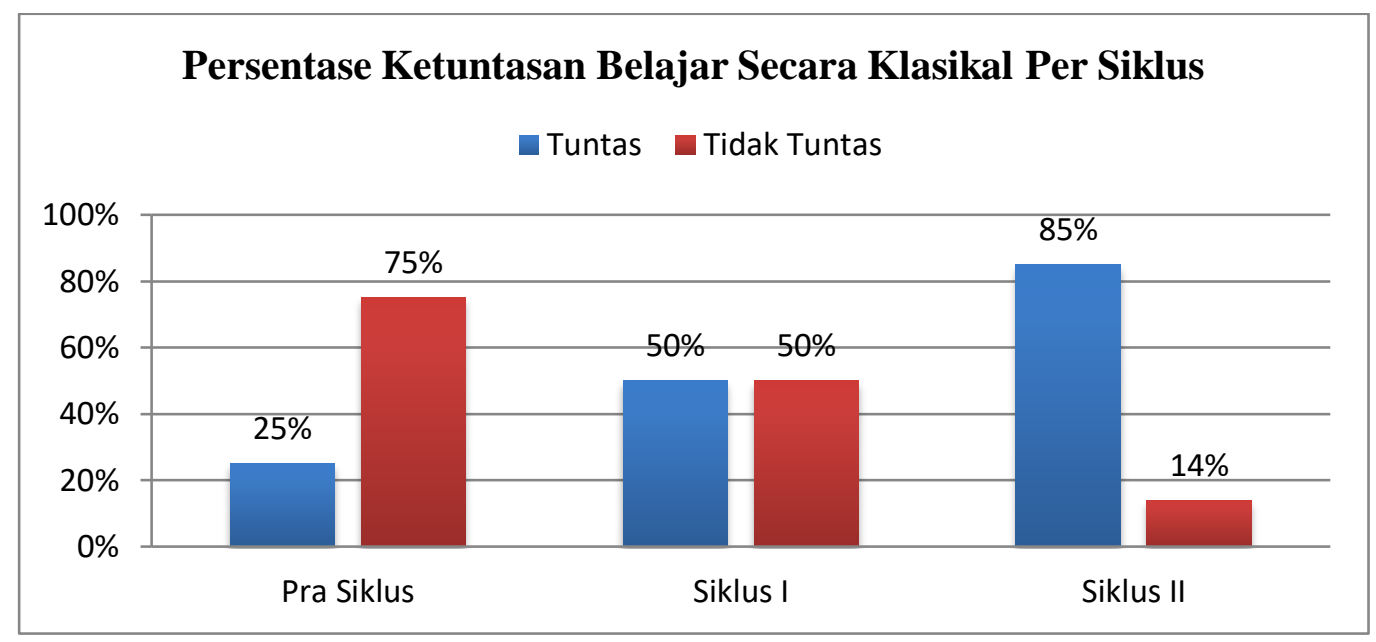

Gambar 1. Presentase Ketuntasan Klasikal

Data hasil tes awal (Pra Siklus) mata pelajaran PPKn materi arti gambar pada lambang negara Garuda Pancasila diperoleh rata-rata untuk hasil belajar siswa adalah sebanyak $55.71 \%$ dari jumlah nilai siswa satu kelas. Jumlah siswa yang mencapai nilai KKM sebanyak 7 siswa dalam bentuk persen yaitu sebanyak $25 \%$ sedangkan untuk siswa yang di bawah nilai KKM sebanyak 21 siswa dalam bentuk persen yaitu sebanyak 75\%, dari 28 siswa kelas III SD Negeri 2 Laompo.

Siklus I sudah sedikit mengalami peningkatan jika dibandingkan pada tes awal/pra siklus dari 28 siswa yang mendapatkan nilai di atas KKM sebanyak 14 siswa dalam bentuknya persennya adalah $50 \%$ dan siswa yang mendapatkan nilai di bawah KKM sebanyak 14 siswa dalam bentuk persennya adalah $50 \%$. Nilai tertinggi dari siklus I adalah 80 sedangkan nilai terendah adalah 60 dengan nilai rata-ratanya adalah $66,42 \%$.

Siklus II sudah masuk kategori baik jika dibandingkan pada tes awal dan siklus I. Siswa yang mendapatkan nilai di atas KKM sebanyak 24 siswa dalam bentuk persennya adalah $85.71 \%$ dan siswa mendapatkan nilai di bawah KKM sebanyak 4 siswa dalam bentuk persennya $14.28 \%$. Nilai tertingginya adalah 100 sedangkan nilai terendahnya adalah 60 dengan nilai rata-rata $77.86 \%$. Pendekatan kontekstual dilakukan dengan memasukkan peristiwa atau objek dari kehidupan sehari-hari siswa. Jenis pembelajaran ini dapat membantu siswa menanggapi masalah apa pun secara efektif. Hal ini dikarenakan siswa sudah familiar dengan permasalahan tersebut dalam kehidupan sehari-hari. (Hasnidar \& Elihami, 2019).

Peningkatan hasil belajar siswa dari kegiatan pra siklus ke siklus I yang meningkat sebanyak 25\%, sedangkan siklus I ke siklus II lebih meningkat sebanyak 35\%. Karena indikator keberhasilan dalam penelitian ini telah tercapai, dalam hal ini terjadi peningkatan hasil belajar siswa secara berkelanjutan dari siklus I ke siklus II maka penelitian ini dihentikan sampai pada siklus II. Karena siswa didorong untuk terlibat secara aktif dan efektif dalam pembelajaran dalam pelatihan ini, maka pembelajaran kontekstual diharapkan sebagai upaya: (1) meningkatkan motivasi dan hasil belajar siswa, (2) menyelesaikan hasil belajar siswa secara bersamaan, baik produk keterampilan, proses, dan keterampilan kinerja. Model pembelajaran Contextual Teaching and Learning (CTL) sangat mudah diaplikasikan pada keseluruhan mata pelajaran mudah diterapkan pada semua mata pelajaran termasuk mata pelajaran PPKn. Siswa akan lebih aktif dalam model pembelajaran yang berbasis pendekatan CTL karena kelompok yang dibuat berukuran kecil, dan setiap siswa mengamati tingkah laku temannya sendiri dan mencari alternatif pemecahan masalah berdasarkan pengamatannya (Jamilah, 2017). Dengan demikian hipotesis tindakan telah terjawab yaitu melalui "Meningkatkan Hasil Belajar PPKn Materi Arti Gambar pada Lambang Negara Garuda Pancasila dengan Menggunakan Model 
Pembelajaran CTL Kelas III SD Negeri 2 Laompo Kabupaten Buton Selatan” dapat ditingkatkan dan dierima dari hasil belajar siswa.

Dalam penelitian model CTL yang digunakan lebih spesifik pada kelas rendah sedangkan pada peneliiti sebelumnya penerapan model CTL lebih banyak digunakan untuk kelas tinggi. Model CTL bisa digunakan pada kelas rendah maupun kelas tinggi. Pada penelitian tersebut masih memiliki Keterbatasan atau hambatan penelitian, sehingga dapat dijadikan sebagai kesempatan pada penelahaan penelitian selanjutnya. Keterbatasan penelitian antara lain siswa lambat dalam memahami penerapan model CTL, di mana siswa belum terbiasa dengan model CTL apalagi diaplikasikan pada kelas rendah, sehingga partisipasi siswa belum maksimal, kurang terbangun komunikasi yang baik pada guru kelas, hasil belajar siswa yang tidak tuntas masih berjumlah 4 siswa, dan peneliti kurang memperhatikan kelas yang menjadi subjek penelitian yang sesuai dengan penerapan CTL. Persamaan pada penelitian sebelumnya memiliki model yang sama yakni model pembelajaran CTL, mata pelajaran PPKn dan hasil belajar siswa. Perbedaan penelitian terdahulu dengan sekarang yakni objek penelitian pada kelas rendah sedangkan terdahulu mengacu pada kelas tinggi. Penelitian ini merupakan penelitian tindakan kelas, tujuan dari perolehan penelitian diharapakan menjadi suatu indikator atau parameter dalam menentukan model pembelejaran yang akan diajarkan di lingkungan sekolah sehingga mendapatkan hasil belajar yang baik. CTL dapat dikombinasikan dengan media teknologi baik berupa video maupun gambar dimensi dalam menjelaskan materi pembelajaran. Model CTL dapat dimanfaatkan sebagai model alternatif yang mana siswa memperolah nilai guna yang terpadu baik secara kognitif, afektif dan psikomotorik siswa sekolah dasar.

Pada dasarnya setiap penelitian memiliki implikasi yang berbeda-beda, baik secara teoritis maupun praktis. Penelitian ini memiliki implikasi teoritis, di mana proses pemilihan dan penentuan model pembelajaran sebagai alernatif yang tepat sangat berpengaruh pada perolehan hasil belajar siswa. Motivasi dan keaktifan dalam pembelajaran sangat penting sehingga guru diharapkan dapat menumbuhkan motivasi belajar demgan berbagai cara dan pada akhirnya akan meningkatkan hasil belajar. Materi dan model pembelajaran dalam penilitian ini diharapkan memlihi dampak yang besar dalam pembentukan kerjasama yang baik. Implikasi secara praktis, hasil penelitian tersebut dapat dijadikan sebagai suatu masukan baik pada guru maupun calon guru. Memperhatikan dan memperbaiki model pembelajaran, sehingga pengajaran yang dilaksanakan dapat meningkatkan hasil belajar siswa sekolah dasar.

\section{KESIMPULAN}

Berdasarkan hasil dan pembahasan penelitian, dapat disimpulkan bahwa menggunakan model CTL pada mata pelajaran PPKn materi Arti Gambar pada Lambang Negara Garuda Pancasila, mengalami peningkatan hasil belajar siswa kelas III SD Negeri 2 Laompo tahun ajaran 2020/2021. Hal ini ditunjukkan dengan tindakan siklus I dan siklus II, nilai rata-rata siklus I $55.71 \%$ dengan ketuntasan belajar klasikal 50\%. Sedangkan siklus II mencapai nilai rata-rata $77,86 \%$ dengan ketuntasan belajar klasikal $85,71 \%$. Jadi nilai siklus II lebih meningkat dibandingkan dengan nilai siklus I. Implikasi penilitian baik secara praktis maupun teoritis menjadi bahan masukan bagi guru dan calon guru dalam pemilihan model pembelajaran untuk meningkatkan hasil maupun prestasi belajar siswa baik pada kelas rendah maupun kelas tinggi pada semua mata pelajaran di sekolah dasar. 
245 Analisis Model Pembelajaran Contextual Teaching and Learning dalam Meningkatkan Hasil Belajar PPKn di Sekolah Dasar - Irwan, Hasnawi

DOI: https://doi.org/10.31004/edukatif.v3i1.343

\section{UCAPAN TERIMA KASIH}

Terima kasih kepada Ibu Dr. Wa Ode Al Zarliani, S.P.,M.M sebagai Rektor UM Buton dan Bapak Acoci, S.Pd.,M.Pd sebagai Ketua Prodi PGSD yang memberikan dukungan dalam proses penelitian, serta ucapan terima kasih kepada sekolah mitra yang meluangkan kesempatan dalam kelengkapan data penelitian.

\section{DAFTAR PUSTAKA}

Aqib, Z., \& Amrullah, A. (2018). ptk penelitian tindakan kelas teori dan aplikasinya. Ptk Penelitian Tindakan Kelas Teori Dan Aplikasinya.

Arikunto, S. (2014). Prosedur Penelitian: Suatu Pendekatan Penelitian. In Rineka Cipta.

Asra, S. (2019). UPAYA MENINGKATKAN AKTIFITAS DAN HASIL BELAJAR PKN PADA MATERI PEMERINTAHAN KABUPATEN KOTA DENGAN MENGGUNAKAN METODE PENDEKATAN CTL (Contextual Teaching And Learning) SISWA KELAS IV SD NEGERI 6 LAWA TAHUN PELAJARAN 2016/2017. Gema Pendidikan. https://doi.org/10.36709/gapend.v26i1.6718

Depdiknas. (2006). PERATURAN MENTERI PENDIDIKAN NASIONAL REPUBLIK INDONESIA NOMOR 22 TAHUN 2006. Global Shadows: Africa in the Neoliberal World Order.

Dwi Putri Yesya \& Desyandri. (2018). PENGARUH PENGGUNAAN MODEL CONTEXTUAL TEACHING AND LEARNING (CTL) DALAM PEMBELAJARAN PKn DI SEKOLAH DASAR. $E$ Journal Pembelajaran Inovasi, Jurnal Ilmiah Pendidikan Dasar.

Hasnidar, H., \& Elihami, E. (2019). Pengaruh Pembelajaran Contextual Teaching Learning Terhadap Hasil Belajar PKn Murid Sekolah Dasar. Mahaguru: Jurnal Pendidikan Guru Sekolah Dasar.

Jamilah, M. (2017). Upaya Meningkatkan Hasil Belajar Siswa Melalui Penerapan Pendekatan Contextual Teaching and Learning (CTL) Pada Mata Pelajaran IPS Di Kelas VI SD Negeri Tatakan 2 Kecamatan Tapin Selatan. Jurnal Pendidikan Kewarganegaraan.

Mandasari, D. S. (2019). PENGEMBANGAN BAHAN AJAR PKN KELAS V YANG BERORENTASI PADA PENDEKATAN CTL (CONTEXTUAL TEACHING AND LEARNING) UNTUK MENINGKATKAN HASIL BELAJAR SISWA SEKOLAH DASAR DI SDN LERPAK 3 BANGKALAN. Jurnal Review Pendidikan Dasar: Jurnal Kajian Pendidikan Dan Hasil Penelitian. https://doi.org/10.26740/jrpd.v5n2.p1003-1008

Pantiwati, Y. (2014). Instrumen Non Tes. Asesmen Pembelajaran Di SD.

Rademan, R., Hasan, S., \& Rusmin, L. (2020). PENERAPAN MODEL PEMBELAJARAN CONTEXTUAL TEACHING AND LEARNING TERHADAP HASIL BELAJAR PKn SISWA KELAS IV SD NEGERI 1 TAPULAGA. Jurnal Ilmiah Pembelajaran Sekolah Dasar. https://doi.org/10.36709/jipsd.v2i1.13692

Rusman, D. . 2013. (2013). Pembelajaran Berbasis Tekhnologi Informasi Dan Komunikasi. Rajawali Pers: Depok Berdasarkan.

S, S. U. (2015). Hasil belajar matematika siswa ditinjau dari interaksi tes formatif uraian dan kecerdasan emosional. Formatif: Jurnal Ilmiah Pendidikan MIPA.

Sudjana, N. (2009). Penilaian Hasil Proses Belajar Mengajar. In Sinarbaru.

Susanto, A. (2013). Teori Belajar dan Pembelajaran di SD. In Biomass Chem Eng.

Suyono, H. (2016). belajar dan pembelajaran teori dan konsep dasar. Bandung:RemajaRosdakarya.

Wahyudin, D., \& Susilana, R. (2011). Inovasi Pendidikan Dan Pembelajaran. Kurikulum Pembelajaran. 